\title{
Morphoagronomic Genetic Diversity in American Wild Rice Species
}

\author{
Elizabeth Ann Veasey $^{1}$, Edson Ferreira da Silva ${ }^{2}$, Eliana Aparecida Schammass ${ }^{3}$, \\ Giancarlo Conde Xavier Oliveira ${ }^{1}$ and Akihiko Ando ${ }^{1}$ \\ ${ }^{I}$ Departamento de Genética, ESALQ/USP; C. P. 83; 13400-970; eaveasey@esalq.usp.br; Piracicaba - SP - Brasil. \\ ${ }^{2}$ Departamento de Biologia; UFRPE; 52171-900; Recife - PE - Brasil. ${ }^{3}$ Centro de Pesquisa e Desenvolvimento de \\ Genética e Reprodução Animal; Instituto de Zootecnia; 13460-000; Nova Odessa - SP - Brasil
}

\begin{abstract}
To characterize the genetic variability among species and populations of South American wild rice, eleven populations of Oryza glumaepatula, seven of $\mathrm{O}$. grandiglumis, four of $\mathrm{O}$. latifolia and one of $\mathrm{O}$. alta, from Brazil and Argentina, were evaluated. A greenhouse experiment was conducted in completely randomized blocks with 23 treatments. Twenty morphoagronomic traits were assessed. Univariate analyses were performed with 16 quantitative traits with the partitioning of populations within species. Significant differences $(p<0.001)$ between species were observed for all the traits as well as among populations within the species. The most variable was $\mathrm{O}$. glumaepatula followed by $\mathrm{O}$. latifolia. Multivariate discriminant canonical and cluster analyses confirmed the separation of the highly diverse $O$. glumaepatula populations from the tetraploid species, and the high genetic variation among $\mathrm{O}$. latifolia populations. Morphological differences among the three tetraploid species seemed to be enough to ascribe them at least the condition of species in statu nascendi.
\end{abstract}

Key words: Brazil, quantitative traits, qualitative traits, morphology, Oryza

\section{INTRODUCTION}

The genus Oryza presents two cultivated species (O. sativa L. and $O$. glaberrima Steud.), and 22 wild species, including the recently discovered $O$. neocaledonica Morat (Lu, 1999). Four wild species of Oryza are known in Central and South America, distributed from Mexico to the North of Argentina: a diploid species $O$. glumaepatula Steud. $\left(2 \mathrm{n}=24, \mathrm{~A}^{\mathrm{gp}} \mathrm{A}^{\mathrm{gp}}\right)$ belonging to the $O$. sativa complex, and three tetraploid species from the $O$. officinalis complex, $O$. alta Swallen, $O$. grandiglumis (Doell) Prod. and O. latifolia Desv. $(2 \mathrm{n}=48, \mathrm{CCDD})$, all occurring in Brazil (Oliveira, 1992). Vaughan (1994) merged both the Asian $O$. rufipogon Griff. and the Neotropical $O$. glumaepatula into one disjunct species, $O$. rufipogon. However, the Neotropical race has been classified in the genome subgroup $\mathrm{A}^{\mathrm{gp}}$, while the Asian race belongs to subgroup $\mathrm{A}$, and similar levels of divergence have been used as partial evidence for giving taxa different species names in other instances in the $O$. sativa complex. The Amazonian morphotype has a unique annual life cycle, composed of a fixed and a floating stage, both flowering, followed by death (Rubim, 1994). Twenty-eight morphological characters were scored for 26 diploid wild rice accessions from South America and Cuba, compared to accessions of $O$. rufipogon and $O$. nivara Sharma and Shastry from Asia, indicating that most of the accessions from South America, now accepted as $O$.

\footnotetext{
${ }^{*}$ Author for correspondence
} 
glumaepatula, were quite distinct from $O$. rufipogon, supporting its distinct taxonomic status (Juliano et al., 1998). Furthermore, high genetic divergence measured with RAPD (Ge et al., 1999a) was found between Amazonian and Chinese $O$. rufipogon, which was considered sufficient for species separation.

Tateoka (1962) found forms intermediate between the Asian-like and the exclusively American populations, which reflected the clinal variation found along the Amazon (Oliveira, 1992). Three different morphotypes (O. glumaepatula I, II, III) were recognized by Akimoto (1999) on the basis of principal components analysis of 22 quantitative characters. The first component was correlated with characters associated to vegetative growth and perenniality and the second component was correlated with reproductive characters and annual life form.

There is much evidence from isozymatic patterns (Grover and Pental, 1992) and molecular analyses (Dally and Second, 1990; Buso et al., 2001), indicating that the Brazilian tetraploid species of genome CCDD were very close genetically and should be considered as a complex or single species and not as distinct species. However, Oliveira (1992) reported a distinct separation between $O$. alta and $O$. grandiglumis, as well as $O$. glumaepatula, with 37 morphophenological characters by multivariate analysis using canonical variables. The distinction between $O$. alta and $O$. grandiglumis, however, became evident only after the inclusion of the reproductive morphological traits, considering that these species were very similar at the vegetative stage.

This work presents the evaluation of 20 morphoagronomical traits in 23 populations representing the four American wild rice species (O. glumaepatula, O. latifolia, $O$. alta and $O$. grandiglumis), collected from several regions in Brazil and Argentina, with the objective of measuring the interspecific and interpopulational genetic diversity and providing data for future inclusion of these species in rice plant breeding programs.

\section{MATERIALS AND METHODS}

In this study, 11 populations of O. glumaepatula, seven populations of $O$. grandiglumis, four populations of $O$. latifolia and one of $O$. alta, collected from several regions of Brazil and Argentina (Table 1), were evaluated. Initially, a bulk of seeds was formed by taking two or three seeds from each family (seeds from individual plants collected in nature) and then mixing them to form a bulk of about 40 seeds for each population. This procedure assured that the populations were represented by different plants of probably different genotypes. These seeds were placed in plastic dishes over a double layer of filter paper previously moistened with distilled water and germinated in the dark at a temperature of $27^{\circ} \mathrm{C}$ in a temperature-controlled incubator. The hulled seeds were previously disinfected with $0.3 \%$ $\mathrm{NaOCl}$ for 5 to $10 \mathrm{~min}$. Germinated seeds were sown in the greenhouse in $67 \times 34 \mathrm{~cm}$ plastic trays, containing a mixture of sand and vermiculite as substrate, watered daily and fertilized with a complete liquid fertilizer every 15 days. After 30 to 40 days, the seedlings were transplanted to $5 \mathrm{~kg}$ plastic bags filled with soil. These were placed in water tanks, measuring 4.50 by $1.30 \mathrm{~m}$, in another greenhouse. The tanks were filled with water up to the plant bases, covering the plastic bags, in order to provide a similar condition to the natural environment of these species (Silva et al., 1999). No fertilizer was applied when transplanting the seedlings as the soil was collected in a high fertility forest environment. The application of Keltane showed good results in controlling a spider mite (Schizotetranychus oryzae Rossi de Simons) attack without damaging the fishes in the water tanks.

The experiment was arranged in a complete block design with three replications and 23 treatments (populations), with four plants in each plot. Thus, each population was represented by 12 individual plants. Plots were $20 \mathrm{~cm}$ apart with $10 \mathrm{~cm}$ between plants within plots.

Sixteen morphoagronomic quantitative traits were evaluated: TN - tiller number, counted on March; $\mathrm{PH}$ - plant height, measured on February, before flowering, from plant base up to the last leaf insertion (mean of three tillers); PHF - plant height at flowering, from plant base up to the flag leaf insertion (mean of three tillers); LL - leaf length, $3^{\circ}$ leaf from the apex (mean of two leaves); LW - leaf width, $3^{\circ}$ leaf from the apex (mean of two leaves); LIGL - ligule length (mean of two ligules); CD culm diameter, in the $2^{\circ}$ culm internode (mean of three culms); DH - days to heading, number of days from $2^{\circ}$ seeding date to the first open panicle; PN - panicle number; PPL - partial panicle length, from the first branching to the tip of the panicle 
(mean of three panicles); TPL - total panicle length, from the panicle base to the tip of the panicle (mean of three panicles); FLL - flag leaf length (mean of three leaves); FLW - flag leaf width (mean of three leaves); SL - spikelet length (mean of five spikelets); SW - spikelet width (mean of five spikelets); AL - awn length (mean of five spikelets). Also, four morphoagronomic qualitative traits were assessed [awn color (straw, purple); stigma color (white, purple); culm angle (erect, intermediate, open, spreading), and spider mite tolerance], with only descriptive observations made.

Table 1 - List of the 23 studied populations, including population code, species identification, hydrographic basin, river and lake or municipality of the original collection sites

\begin{tabular}{|c|c|c|c|c|c|c|c|}
\hline $\mathbf{N}^{\mathbf{o}}$ & Code & Species & $\begin{array}{c}\text { Hydrographic } \\
\text { Basin }\end{array}$ & River & $\begin{array}{c}\text { Lake } \\
\text { (Municip.) }\end{array}$ & Latitude & $\begin{array}{l}\text { Longi- } \\
\text { tude }\end{array}$ \\
\hline 1 & RJP-3 & O. grandiglumis & Japurá & Japurá & - & $2^{\circ} 40^{\prime} \mathrm{S}$ & $64^{\circ} 57^{\prime} \mathrm{W}$ \\
\hline 2 & RP-2 & O. grandiglumis & Purus & Purus & Bravo & $3^{\circ} 51^{\prime} \mathrm{S}$ & $61^{\circ} 26^{\prime} \mathrm{W}$ \\
\hline 3 & RS-10 & O. grandiglumis & Solimões & - & Miuá & $3^{\circ} 50^{\prime} \mathrm{S}$ & $62^{\circ} 05^{\prime} \mathrm{W}$ \\
\hline 4 & RS-14 & O. grandiglumis & Solimões & - & Jucara & $4^{\circ} 02^{\prime} \mathrm{S}$ & $63^{\circ} 08^{\prime} \mathrm{W}$ \\
\hline 5 & RS-3 & O. grandiglumis & Solimões & - & Paru & $3^{\circ} 18^{\prime} \mathrm{S}$ & $60^{\circ} 35^{\prime} \mathrm{W}$ \\
\hline 6 & RS-26 & O. grandiglumis & Solimões & - & Caldeirão & $3^{\circ} 15^{\prime} \mathrm{S}$ & $60^{\circ} 11^{\prime} \mathrm{W}$ \\
\hline 7 & RSJN-3 & O. grandiglumis & Solimões & - & Janauacá & $3^{\circ} 19^{\prime} \mathrm{S}$ & $60^{\circ} 11^{\prime} \mathrm{W}$ \\
\hline 8 & RJP-4 & O. glumaepatula & Japurá & Japurá & Cuiucuiú & $2^{\circ} 22 \mathrm{~S}$ & $65^{\circ} 07^{\prime} \mathrm{W}$ \\
\hline 9 & $\mathrm{RN}-18$ & O. glumaepatula & Negro & Branco & - & $1^{\circ} 53^{\prime} \mathrm{S}$ & $61^{\circ} 22^{\prime} \mathrm{W}$ \\
\hline 10 & $\mathrm{RN}-21$ & O. glumaepatula & Negro & Branco & Dauaú & $1^{\circ} 58^{\prime} \mathrm{S}$ & $61^{\circ} 52^{\prime} \mathrm{W}$ \\
\hline 11 & $\mathrm{RN}-7$ & O. glumaepatula & Negro & Negro & - & $1^{\circ} 24^{\prime} \mathrm{S}$ & $61^{\circ} 59^{\prime} \mathrm{W}$ \\
\hline 12 & RN-9 & O. glumaepatula & Negro & Jauaperi & Grande & $1^{\circ} 26^{\prime} \mathrm{S}$ & $61^{\circ} 34^{\prime} \mathrm{W}$ \\
\hline 13 & RPG-1 & O. glumaepatula & Paraguai & Paraguai & - & $19^{\circ} 01 ' \mathrm{~S}$ & $57^{\circ} 30^{\prime} \mathrm{W}$ \\
\hline 14 & RP-1 & O. glumaepatula & Purus & Purus & - & $3^{\circ} 49^{\prime} \mathrm{S}$ & $61^{\circ} 25^{\prime} \mathrm{W}$ \\
\hline 15 & RS-14 & O. glumaepatula & Solimões & - & Jucara & $4^{\circ} 02^{\prime} \mathrm{S}$ & $63^{\circ} 08^{\prime} \mathrm{W}$ \\
\hline 16 & RS-9 & O. glumaepatula & Solimões & - & Anori & $3^{\circ} 49^{\prime} \mathrm{S}$ & $61^{\circ} 36^{\prime} \mathrm{W}$ \\
\hline 17 & RSJN-3 & O. glumaepatula & Solimões & - & Janauacá & $3^{\circ} 19^{\prime} \mathrm{S}$ & $60^{\circ} 11^{\prime} \mathrm{W}$ \\
\hline 18 & RT-1 & O. glumaepatula & Tapajós & Tapajós & - & $2^{\circ} 26^{\prime} \mathrm{S}$ & $54^{\circ} 42^{\prime} \mathrm{W}$ \\
\hline 19 & ARG-5 & O. latifolia & Paraguai/Paraná & Paraguai & - & $27^{\circ} 18^{\prime} \mathrm{S}$ & $59^{\circ} 24^{\prime} \mathrm{W}$ \\
\hline 20 & ARG-8 & O. latifolia & Paraguai/Paraná & Paraguai & - & $27^{\circ} 26 \mathrm{~S}$ & $58^{\circ} 52^{\prime} \mathrm{W}$ \\
\hline 21 & RTAQ- & O. latifolia & Paraguai & Taquari & Pantanal & $19^{\circ} 15^{\prime} \mathrm{S}$ & $57^{\circ} 13^{\prime} \mathrm{W}$ \\
\hline 22 & RPG-1 & O. latifolia & Paraguai & Paraguai & Pantanal & $19^{\circ} 01 ' \mathrm{~S}$ & $57^{\circ} 30^{\prime} \mathrm{W}$ \\
\hline 23 & RR-1 & O. alta & Ribeira & Ribeira & (Iguape) & - & - \\
\hline
\end{tabular}

Univariate analyses were performed using SAS (SAS Institute, 1993) for the 16 quantitative traits, with the partitioning of populations within species (Table 2), according to the mathematical model:

$Y_{i j k l}=\mu+\alpha_{i}+\beta_{l(i)}+\delta_{j}+e_{(i j l)}+d_{k(i j l)}$

Where $\mu=$ overall character mean; $\alpha_{i}=$ fixed effect of $\mathrm{i}^{\text {th }}$ species $(\mathrm{i}=1, \ldots, 4) ; \beta_{1(i)}=$ fixed effect of $1^{\text {th }}$ population, within $\mathrm{i}^{\text {th }}$ species $(1=1, \ldots, 11) ; \delta_{j}$ $=$ random effect of $\mathrm{j}^{\text {th }}$ block $(\mathrm{j}=1, . ., 3) ; e_{(i j l)}=$ random effect of plot error of $\mathrm{ijl}^{\text {th }}$ plot; $d_{k(i j l)}=$ random effect of $\mathrm{k}^{\text {th }}$ individual, in the $\mathrm{ij}^{\mathrm{j}} \mathrm{t}^{\text {th }}$ plot $(\mathrm{k}=$ $1, . .4)$. Due to the different number of populations per species, a coefficient $(\bar{c})$ was calculated, according to the following equation: 


$$
\bar{c}=\frac{1}{p-1}\left(\sum_{i=1}^{p} c_{i}-\frac{\sum_{i} C i^{2}}{\sum_{i}^{C} C i}\right) \text {, where } p=\mathrm{n}^{\mathbf{o}} \text { of }
$$

species; $c_{i}=\mathrm{n}^{\mathrm{o}}$ of populations of the $\mathrm{i}^{\text {th }}$ species. The phenotypic variance within species $\left(\hat{\sigma}_{d}^{2}\right)$, the error variance among plots $\left(\hat{\sigma}_{e}^{2}\right)$, the genetic diversity among species $\left(\hat{V}_{\alpha}\right)$, and populations within O. grandiglumis $\left(\hat{V}_{\alpha_{1}}\right)$, O. glumaepatula $\left(\hat{V}_{\alpha_{2}}\right)$, and $O$. latifolia $\left(\hat{V}_{\alpha_{3}}\right)$, were estimated according to the following equations ( $S_{1}$ to $S_{7}$ defined in Table 2):

$$
\begin{gathered}
\hat{\sigma}_{d}^{2}=S_{1}=M S_{d} ; \quad \hat{\sigma}_{e}^{2}=S_{2}-S_{1} / k ; \\
\hat{V}_{\alpha}=\left(S_{7}-S_{2}\right) / k \bar{c} J ; \hat{V} \alpha_{1}=\left(S_{5}-S_{2}\right) / k J ; \\
\hat{V}_{\alpha_{2}}=\left(S_{4}-S_{2}\right) / k J ; \hat{V} \alpha_{3}=\left(S_{3}-S_{2}\right) / k J .
\end{gathered}
$$

Multivariate analyses were also conducted using the 16 quantitative traits, including a cluster analysis with the UPGMA method and Euclidean distances, and a principal component analyses, using SAS (SAS Institute, 1993) and Statistica for Windows (Statsoft, 1996) programs.

Table 2 - Sources of variation, degrees of freedom (d.f.), and expected mean squares (MS) of the analysis of variance for the morpho-agronomic traits

\begin{tabular}{lccc}
\hline Sources of variation & d.f. & MS & Expectation of mean squares \\
\hline Blocks & $(J-1)$ & $S_{8}$ & - \\
Species & $(I-1)$ & $S_{7}$ & $\sigma_{d}^{2} / \bar{k}+\sigma_{e}^{2}+J \bar{c} V_{\alpha}$ \\
Populations/species & $I(\bar{L}-1)$ & $S_{6}$ & $\sigma_{d}^{2} / \bar{k}+\sigma_{e}^{2}+J V_{\beta}$ \\
$\quad$ Populations/O. grandiglumis & $\left(L_{1}-1\right)$ & $S_{5}$ & $\sigma_{d}^{2} / \bar{k}+\sigma_{e}^{2}+J V_{\beta 1}$ \\
$\quad$ Populations/O. glumaepatula & $\left(L_{2}-1\right)$ & $S_{4}$ & $\sigma_{d}^{2} / \bar{k}+\sigma_{e}^{2}+J V_{\beta 2}$ \\
$\quad\left(L_{3}-1\right)$ & $S_{3}$ & $\sigma_{d}^{2} / \bar{k}+\sigma_{e}^{2}+J V_{\beta 3}$ \\
Populations/O. latifolia & $(I \bar{L}-1)(J-1)$ & $S_{2}$ & $\sigma_{d}^{2} / \bar{k}+\sigma_{e}^{2}$ \\
Error & $J I \bar{L}(K-1)$ & $S_{1}$ & $\sigma_{d}^{2}$ \\
\hline
\end{tabular}

\section{RESULTS AND DISCUSSION}

Significant differences $(\mathrm{p}<0.001)$ between species were observed for all the traits (Tables 3 and 4). Significant differences $(\mathrm{p}<0.001)$ were also observed among populations within species, such as $O$. glumaepatula for all the 16 traits, showing a remarkable amount of variation. The second most variable species was $O$. latifolia, with significant differences $(\mathrm{p}<0.05)$ for 13 traits. Zamora et al. (1999) also observed high diversity in morphological characters in $O$. latifolia populations from Costa Rica, such as seed size, plant height, and in the color of structures such as awn, branches, ligule, auricles and nodes. $O$. grandiglumis was the least variable, with significant differences for nine traits. These findings agreed with the phylogenetic studies conducted by Oliveira (2002) and Ge et al. (1999b), indicating that $O$. grandiglumis was of more recent origin.

The high genetic variation among populations of O. glumaepatula was observed especially for the traits tiller number, plant height at flowering, leaf length and width, culm length, days to heading, number of panicles, panicle height, flag leaf length, spikelet length and awn length (Tables 3 and 4). Vaughan (1994) reported the Latin American race of $O$. rufipogon, later reclassified as O. glumaepatula (Juliano et al., 1998; Ge et al., 1999b), having spikelets up to $11 \mathrm{~mm}$ in length, in contrast to the usual 8-9 mm spikelets of Asian $O$. rufipogon. Agreeing with Vaughan's (1994) observations, this work found spikelet lengths varying from $8.1 \mathrm{~mm}$ to $11.3 \mathrm{~mm}$ (Table 4). Shimamoto et al. (1994) observed seed lengths varying from $8.6 \mathrm{~mm}$ to $10.7 \mathrm{~mm}$ in $O$. glumaepatula populations from the Amazon region. Vaughan (1994) also recorded awns up to 
$16 \mathrm{~cm}$ in the Latin American race $(O$. glumaepatula), whereas the Asian races were usually $6-10 \mathrm{~cm}$ long. In this work, the awns examined ranged from $3.09 \mathrm{~cm}$ to $9.42 \mathrm{~cm}$, much smaller than the Latin American populations examined by Vaughan (1994).

Table 3 - Variance estimates between $\left(V_{\alpha}\right)$ and within $\left(V_{\beta i}\right)$ species of Oryza spp., coefficients of variation (CV) and variation range (minimum-maximum, original data) for the traits: tiller number $(\mathrm{TN})$, plant height $(\mathrm{PH})$ and plant height at flowering (PHF), leaf length (LL) and width (LW), ligule length (LIGL), culm diameter (CD) and days to heading $(\mathrm{DH})$

\begin{tabular}{|c|c|c|c|c|c|c|c|c|}
\hline Sources of variation & $\begin{array}{l}T N^{1} \\
\left(n^{0}\right)\end{array}$ & $\begin{array}{l}\mathbf{P H}^{2} \\
(\mathbf{m})\end{array}$ & $\begin{array}{c}\text { PHF } \\
(\mathrm{m})\end{array}$ & $\begin{array}{c}\mathbf{L L} \\
(\mathrm{cm})\end{array}$ & $\begin{array}{l}\mathbf{L W}^{2} \\
(\mathrm{~cm})\end{array}$ & $\begin{array}{c}\text { LIGL }^{1} \\
(\mathrm{~mm})\end{array}$ & $\begin{array}{c}\mathrm{CD} \\
(\mathbf{m m})\end{array}$ & $\begin{array}{l}\text { DH } \\
\left(n^{\circ}\right)\end{array}$ \\
\hline Species $\left(V_{\alpha}\right)$ & $0.6566^{\mathrm{a} 3}$ & $0.0237^{\mathrm{a}}$ & $\underset{\substack{a \\
1740.3248}}{ }$ & $31.7292^{\mathrm{a}}$ & $0.0321^{\mathrm{a}}$ & $0.1962^{\mathrm{a}}$ & $0.5030^{\mathrm{a}}$ & $647.5458^{\mathrm{a}}$ \\
\hline \multicolumn{9}{|l|}{ Populations/species: } \\
\hline O. glumaepatula $\left(V_{\beta 1}\right)$ & $1.3929^{\mathrm{a}}$ & $0.0053^{\mathrm{a}}$ & $\underset{\mathrm{a}}{1314.8758}$ & $47.2821^{\mathrm{a}}$ & $0.0032^{\mathrm{a}}$ & $0.0043^{\mathrm{a}}$ & $0.5340^{\mathrm{a}}$ & $650.0063^{\mathrm{a}}$ \\
\hline O. grandiglumis $\left(V_{\beta 2}\right)$ & $0.0095^{\mathrm{ns}}$ & $0.0025^{\mathrm{a}}$ & $84.5216^{\mathrm{b}}$ & $4.6989^{c}$ & $0.0001^{\mathrm{ns}}$ & $0.0003^{\text {ns }}$ & $0.1360^{\mathrm{a}}$ & $74.7975^{\mathrm{b}}$ \\
\hline O. latifolia $\left(V_{\beta 3}\right)$ & $\cong 0.0000^{\mathrm{ns}}$ & $0.0311^{\mathrm{a}}$ & $\begin{array}{c}5395.8287 \\
a\end{array}$ & $72.4047^{\mathrm{a}}$ & $0.0023^{\mathrm{a}}$ & $0.0042^{\mathrm{a}}$ & $0.7547^{\mathrm{a}}$ & $1532.5774^{\mathrm{a}}$ \\
\hline $\mathrm{CV}(\%)$ & 7.90 & 1.69 & 7.71 & 4.99 & 10.60 & 2.76 & 3.99 & 4.49 \\
\hline O. glumaepatula & $10.00-69.00$ & $0.35-0.77$ & $\begin{array}{c}1.10- \\
2.46\end{array}$ & $\begin{array}{l}49.50- \\
82.95\end{array}$ & $\begin{array}{c}1.02- \\
1.75\end{array}$ & $\begin{array}{c}24.62- \\
46.87\end{array}$ & $3.82-6.84$ & $116.25-209.75$ \\
\hline O. grandiglumis & $\begin{array}{l}8.00- \\
15.25\end{array}$ & $0.74-1.17$ & $\begin{array}{l}1.96- \\
2.94\end{array}$ & $\begin{array}{l}52.02- \\
64.15\end{array}$ & $2.35-3.07$ & $\begin{array}{l}5.75- \\
7.62\end{array}$ & $6.18-7.85$ & $168.25-205.25$ \\
\hline O. latifolia & $\begin{array}{l}11.25- \\
20.50\end{array}$ & $0.70-1.83$ & $\begin{array}{c}1.23- \\
3.07\end{array}$ & $\begin{array}{l}46.22- \\
70.47\end{array}$ & $\begin{array}{l}1.90- \\
2.80\end{array}$ & $\begin{array}{c}5.12- \\
9.00\end{array}$ & $4.75-7.16$ & $90.00-166.50$ \\
\hline O. alta & $7.50-8.25$ & $0.47-0.58$ & $\begin{array}{l}1.84- \\
2.12\end{array}$ & $\begin{array}{c}55.70- \\
63.02 \\
\end{array}$ & $\begin{array}{c}2.60- \\
3.00\end{array}$ & $\begin{array}{c}4.87- \\
5.25 \\
\end{array}$ & $6.61-7.06$ & $114.75-117.00$ \\
\hline
\end{tabular}

${ }^{1}$ Data transformed into $\sqrt{x} ;{ }^{2}$ Data transformed into $\log (\mathrm{x}) ;{ }^{3}$ Significant at $\mathrm{p}<0.001$ (a), $\mathrm{p}<0.01$ (b), $\mathrm{p}<0.05$ (c), non-significant (ns)

Table 4 - Variance estimates between $\left(V_{\alpha}\right)$ and within $\left(V_{\beta i}\right)$ species of Oryza spp., coefficients of variation (CV) and variation range (minimum-maximum, original data) for the traits: panicle number (PN), total panicle length (TPL), partial panicle length (PPL), flag leaf length (FLL) and width (FLW), spikelet length (SL) and width (SW) and awn length (AL)

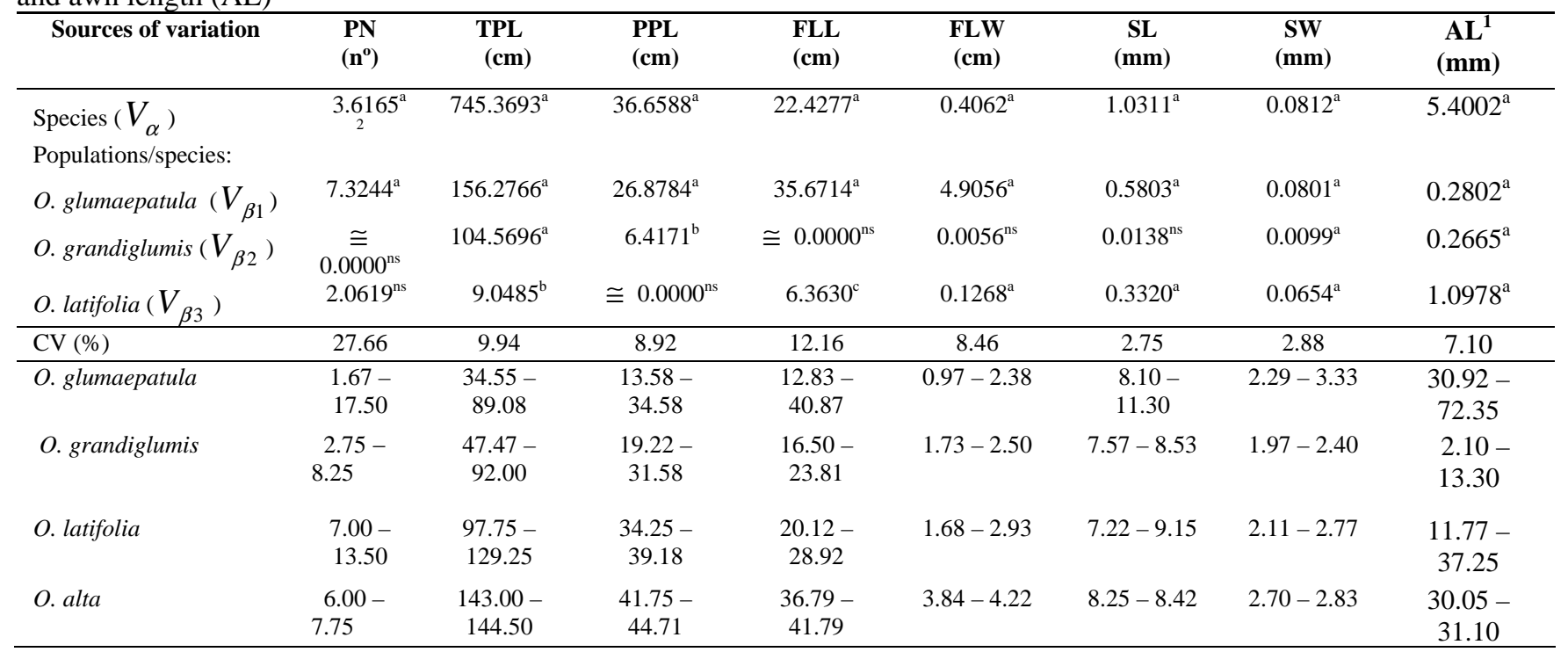

${ }^{1}$ Data transformed into $\sqrt{x} ;{ }^{2}$ Significant at $\mathrm{p}<0.001$ (a), $\mathrm{p}<0.01$ (b), $\mathrm{p}<0.05$ (c), non-significant (ns) 
Stigma color, one of the evaluated qualitative traits, varied among and within O. glumaepatula populations. RP-1, RS-9 and RSJN-3 populations presented $100 \%$ white stigmas, whereas populations RJ-4, RN-21, RPG-1 and RT-1 showed $100 \%$ purple stigmas. RS-14, RN-7, RN-9 and $\mathrm{RN}-18$ populations presented purple stigmas in, respectively, $42,58,58$ and $64 \%$ of the plants evaluated. For the other species, only white stigmas were observed. Therefore, this was a highly polymorphic morphological trait and interesting morphological marker for $O$. glumaepatula. Awn color was another polymorphic trait for O. glumaepatula, with some populations showing a purple color, such as RPG1 (92\%), RT-1 (67\%) and RS-14 (25\%) when compared to the straw color usually observed for most populations.

Culm angle was also assessed, with most populations showing an erect or intermediate angle. A spreading growth habit was observed only for populations RT-1 of $O$. glumaepatula, ARG-8 of $O$. latifolia and RR-1 of $O$. alta. Another qualitative and agronomic trait evaluated was spider mite tolerance. The most sensitive to this pest was $O$. glumaepatula populations, followed by $O$. latifolia in a lesser intensity.

For the discriminant canonical analysis, the first two axis represented $76 \%$ of total variance. The first canonical axis showed a clear separation of $O$. glumaepatula populations, to the right side of the graph, from the three tetraploid species, scattered towards the left side (Fig. 1). On the second canonical axis, a further separation was observed among $O$. glumaepatula populations, mainly those from Rio Negro. RN-18 was closer to the other populations, but $\mathrm{RN}-7$, RN-9 and $\mathrm{RN}-21$ were clustered together and more distant from the others, indicating the occurrence of a strong differentiation in that basin. These three populations began flowering in March, earlier than the other $O$. glumaepatula populations which began flowering in April and May. They also presented the lowest ligule lengths and the highest panicle number, with a high seed yield (data not shown).

Rio Negro is characterized by highly acid black water, as its name indicates, with $\mathrm{pH}$ around 4.6 to 5.5 (Shimamoto et al., 1994), with little suspended particles, poor in mineral elements and more transparent than the white-water rivers of the Amazon, such as Solimões, Purus, Madeira, Jurua and Jutai. Therefore, it is not surprising that differences in morphology are to be found among the different river systems in the Amazon. Morphometric differentiation based on fruit and seed traits among river basins (Japurá, Solimões, Purus and Ji-Parana) in the Amazon were also studied in cacao (Theobroma cacao L), with the cacao diversity found predominantly in trees within basins and among basins (Dias et al., 2003). According to Shimamoto et al. (1994), $O$. glumaepatula is commonly found on the lower basin of the Rio Negro and three tributaries (Rio Branco, Unini and Jau), with a lower frequency of occurrence upstream.

The second canonical axis also separated $O$. latifolia, with the Argentinean populations placed away from each other and even further from those collected in the Paraguay River System. These data confirmed the univariate analyses results, showing a higher variability for this species, the second most variable after $O$. glumaepatula. $O$. alta was separated from all the other populations, while $O$. grandiglumis populations were grouped together, also confirming the univariate analyses results.

Similar results are shown in the cluster analysis (Fig. 2). Three main groups were observed, which were further divided into 10 groups. The first main group comprehended the single population of $O$. alta (group 1), which differed from the other species and populations by showing lower tiller number and plant height, higher total and partial panicle length, and higher length and width of the flag leaf. The second main group clustered $O$. glumaepatula populations, subdivided into five groups. Group 2 contained the single Rio Purus population, mainly because of the higher tiller number presented. Group 3 clustered together RSJN-3 and RS-9 populations, while group 4 classified the four Rio Negro populations. Groups 3 and 4 presented the lower tiller numbers. As already discussed above, the Rio Negro populations (group 4) were early flowering, and also presented the lowest ligule lengths, the highest leaf lengths and highest panicle numbers. The single population evaluated from the Pantanal area in the Paraguay River System (group 5) presented high tiller number, but lower than RP-1, 
the highest ligule length, the highest spikelet length as well as the highest awn length. Group 6 classified three populations from Rio Tapajos, Rio Solimões and Rio Japura, which presented the highest ligule lengths, similarly to RPG-1 population. Therefore, a greater morphological genetic variability was observed among $O$. glumaepatula populations, followed by $O$. latifolia populations.

The two species, $O$. latifolia and $O$. grandiglumis, were clustered together in a third main group, which was further separated into three groups. The two Argentinean populations differed from each other in plant heights, with ARG-8 (group 7) being taller than ARG-5 (group 8). These two populations differed from the others mainly due to flowering time. They began flowering in February, while $O$. alta began in March and all the other tetraploid populations began flowering only in April and May. They presented also a higher panicle number, similar to the earlier flowering Rio Negro $O$. glumaepatula populations. On the other hand, the two $O$. latifolia populations from the Pantanal ecosystem (group 9) presented higher plant heights at flowering, up to $2.97 \mathrm{~m}$. Group 10 clustered the seven $O$. grandiglumis populations, with also higher plant heights.
An aspect that could be explored based on these morphological data was the taxonomic status of the three tetraploid (CCDD) Neotropical species. Almost all authors agreed that these species were morphologically very similar and others considered that the differences would only be sufficient to separate them in subspecies (Gopalakrishnan and Sampath 1967); however, most gave each one species status. Enzymatic patterns and molecular data (Dally and Second, 1990; Grover and Pental, 1992; Buso et al., 2001) have shown that these three species were genetically very similar, and should be classified as a single species or a species complex. On the other hand, some morphometric studies showed that the overlapping among the CCDD species was small or lacking. After a canonical variables analysis using 37 morphophenological traits and the three first variables, Oliveira (1992) observed a clear separation between $O$. alta and $O$. grandiglumis.

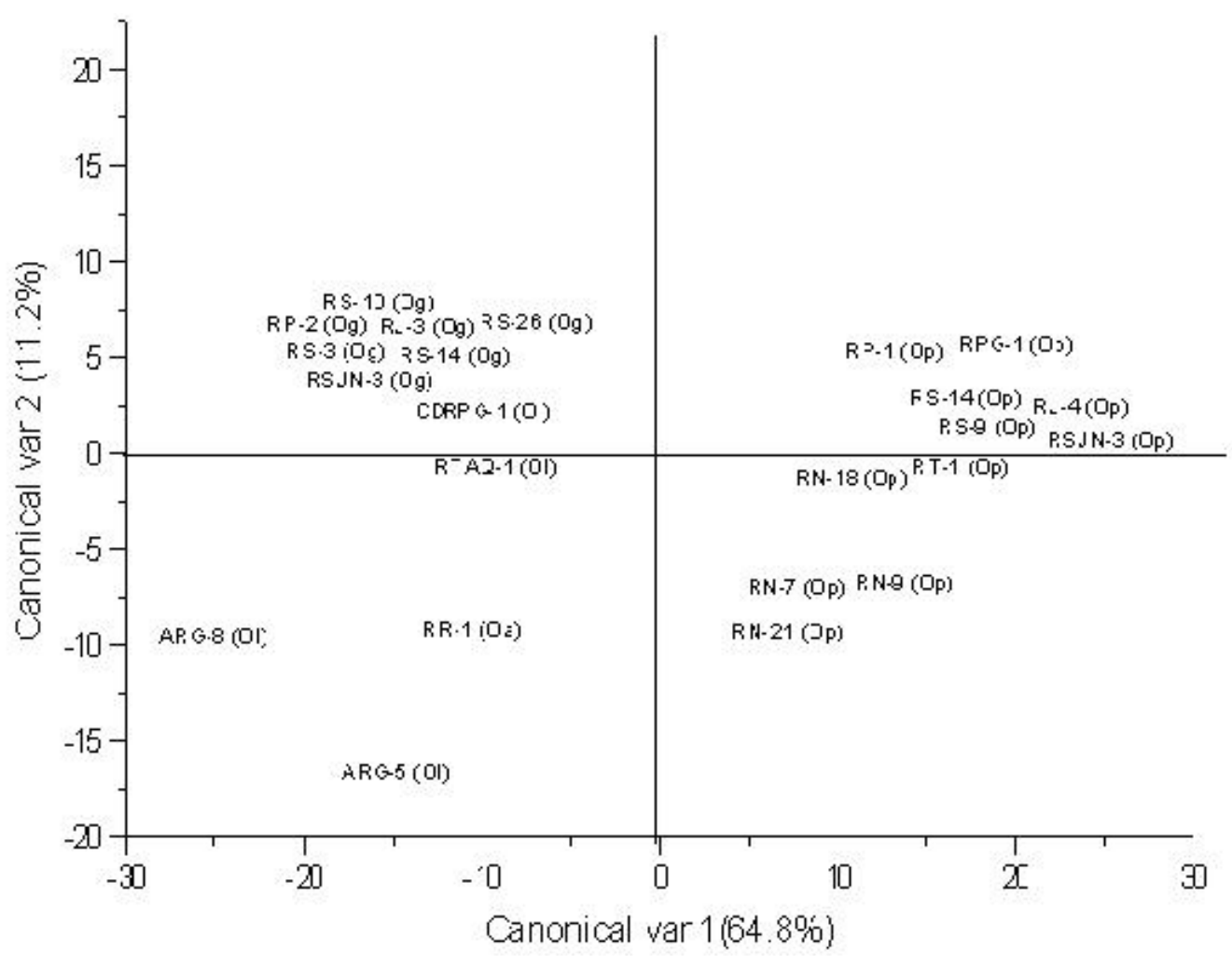


Figure 1 - Scatter graph representing 23 Oryza glumaepatula (Op), O. latifolia (Ol), O. grandiglumis $(\mathrm{Og})$ and $O$. Alta $(\mathrm{Oa})$ populations plotted against the two first canonical variables

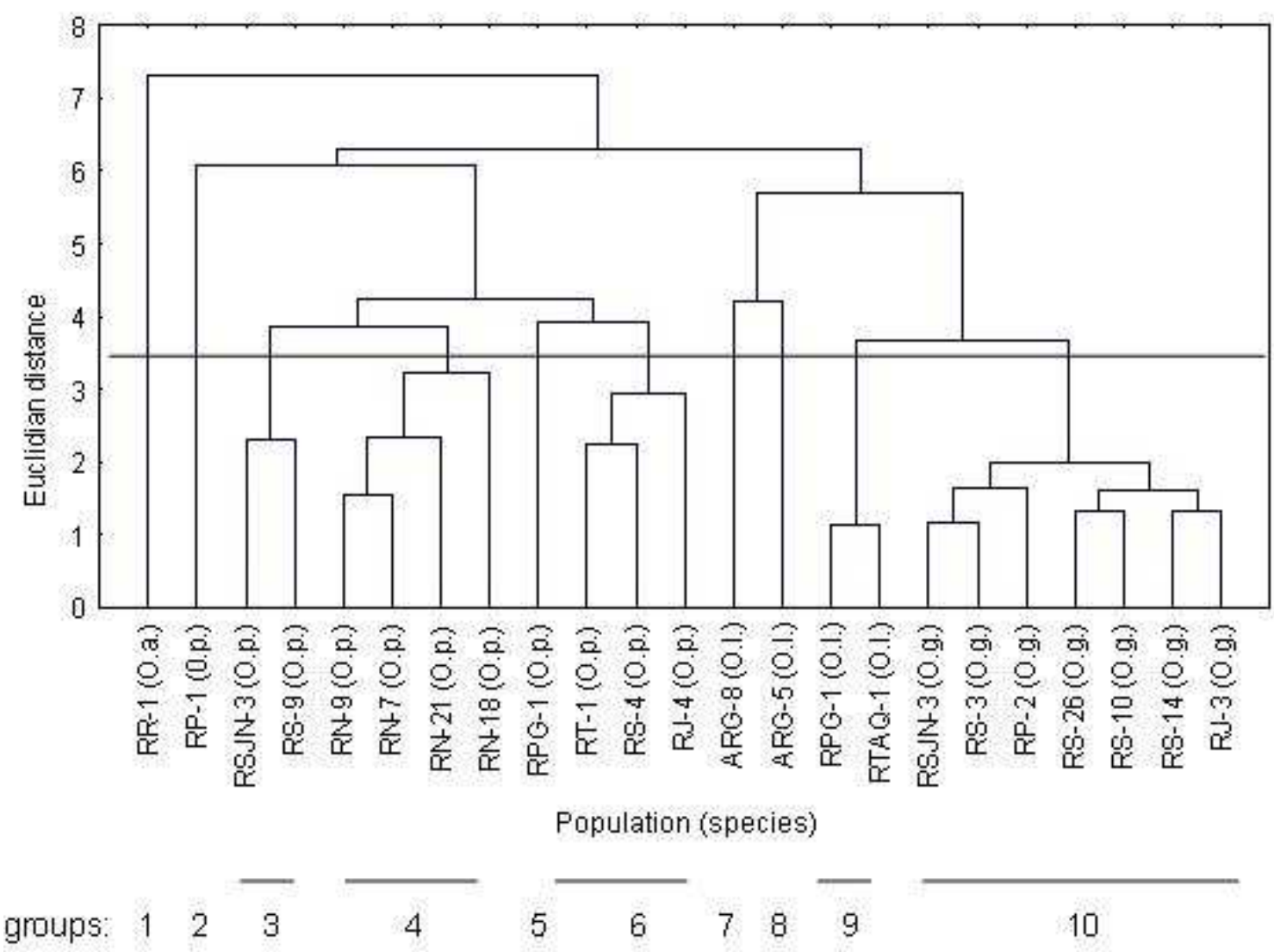

Figure 2 - Cluster analysis dendrogram with 16 morpho-agronomic traits of Oryza glumaepatula (O.p.), O. latifolia (O.1.), O. grandiglumis (O.g.) and O. alta (O.a.) populations, based on Euclidean distance and the UPGMA method

In a study based on 20 contour variables expressing the shape and size of the spikelet (Oliveira, 2002), the three tetraploid species did not overlap much on a principal components graph except for a partial overlap between $O$. grandiglumis and $O$. latifolia, which was also observed in the present study. When size was suppressed, the degree of overlapping among the three CCDD species increased substantially, showing that most of the differences among species were due to size. The geographic distribution of these three species was not concentric but parapatric, existing contact zones, however, where two species could be found as the end types of a hybrid swarm continuum (Oliveira, 1994).

In the cluster analysis, a problem was posed by the single $O$. alta population (RR-1) originated from Rio Ribeira in the State of São Paulo, which was quite differentiated from the other species or populations. That $O$. alta, which included RR-1, was part of the CCDD complex (whether one considered this complex as composed of 1 or 3 species), was widely accepted, and corroborated by cytogenetic, hybridological and molecular evidence (Ge et al., 1999b; Oliveira, 2002). There seemed also to be enough morphological differences among the three CCDD species to 
ascribe them at least the condition of species in statu nascendi. Thus, the separation of RR-1 ( $O$. alta) from the other CCDD species in the cluster analysis indicated that the particular set of traits included in this study differentiated the RR-1 population at a rate higher than that displayed for the genome as a whole.

The distance between the RR-1 population of $O$. alta and the cluster formed by the populations of $O$. latifolia and $O$. grandiglumis was larger than both the distance between $O$. glumaepatula and both $O$. grandiglumis and $O$. latifolia. This indicated either a strong selective pressure or genetic drift pressure underlying the divergence, although it was difficult at present to say whether such pressures were still acting or had ceased.

The morphometric divergence among the populations of the three CCDD species was greater than that presented by the $O$. glumaepatula populations. This did not provide compelling evidence in favor of clumping the CCDD species into one single species. Some populations of $O$. latifolia were closer to $O$. grandiglumis than to the other $O$. latifolia populations, and the $O$. alta population was inserted in the area occupied by $O$. latifolia, showing that the three species were not completely differentiated, and corroborating the status of nascent species.

In agreement with other studies, these analyses showed a large amount of variation in morphoagronomic characters, which could have the potential to be used both for rice breeding purposes and in ecogenetic and evolutionary research programs.

\section{ACKNOWLEDGEMENTS}

The authors are grateful to the Fundação de Amparo à Pesquisa do Estado de São Paulo (FAPESP) for financial support of this research and to the Conselho Nacional de Desenvolvimento Científico e Tecnológico (CNPq) for research fellowships.

\section{RESUMO}

Visando caracterizar a diversidade genética entre espécies e populações de arroz selvagem da América do Sul, foram avaliadas 11 populações de Oryza glumaepatula, sete de $O$. grandiglumis, quatro de $O$. latifolia e uma população de $O$. alta, originárias do Brasil e Argentina. Foi conduzido um experimento em casa-de-vegetação em blocos ao acaso com 23 tratamentos. Vinte caracteres agro-morfológicos foram avaliados. Análises univariadas foram realizadas para 16 caracteres quantitativos, desdobrando-se o efeito de populações dentro de espécies. Diferenças significativas $(p<0,001)$ entre espécies foram observadas para todos os caracteres bem como entre populações dentro de espécies. A mais variável foi $O$. glumaepatula seguida de $O$. latifolia. Análises de agrupamento e discriminante canônica confirmaram a separação das populações de $O$. glumaepatula das espécies tetraplóides, e a grande variação genética entre populações de $O$. latifolia. Diferenças morfológicas entre as três espécies tetraplóides parecem suficientes para classificá-las como espécies pelo menos na condição statu nascendi.

\section{REFERENCES}

Akimoto, M. (1999), Bio-systematics of the Oryza AA genome wild taxa (Oryza sativa complex) by morpho-physiological traits, isozyme and RFLPs. PhD Thesis, Hokkaido University, Sapporo, Japan.

Buso, G.S.C.; Rangel, P.H.N. and Ferreira, M.E. (2001), Analysis of random and specific sequences of nuclear and cytoplasmic DNA in diploid and tetraploid American wild rice species (Oryza spp.). Genome 44, 476-494.

Dally, A.M. and Second, G. (1990), Chloroplast DNA diversity in wild and cultivated species of rice (genus Oryza, section Oryza). Cladistic-mutation and genetic distance analysis. Theor. Appl. Genet., 80, 209-223.

Dias, L.A.S.; Barriga, J.P.; Kageyama, P.Y.; Almeida, C.M.V.C. (2003) Variation and its distribution in wild cacao populations from the Brazilian Amazon. Braz. Arch. Biol. Technol., 46, 507-514.

Ge, S.; Oliveira, G.C.X.; Schaal, B.A.; Gao, L.Z. and Hong, D.Y. (1999a), RAPD variation within and between natural populations of the wild rice Oryza rufipogon from China and Brazil. Heredity, 82, 638644.

Ge, S.; Sang, T.; Lu, B. and Hong, D. (1999b), Phylogeny of rice genomes with emphasis on origins of allotetraploid species. Proc. Natl. Acad. Sci. U.S.A., 96, 14400-14405.

Gopalakrishnan, R and Sampath, S (1967), Taxonomic status and origin of American tetraploid species of the series latifoliae Tateoka in the genus Oryza. Indian J. Agric. Sci., 37, 465-475.

Grover, A. and Pental, D. (1992), Interrelationships of Oryza species based on electrophoretic patterns of alcohol dehydrogenase. Can. J. Bot., 70, 352-358. 
Juliano, A.B.; Naredo, M.E.B. and Jackson, M.T. (1998), Taxonomic status of Oryza glumaepatula Steud. I. Comparative morphological studies of New World diploids and Asian AA genome species. Genet. Resour. Crop Evol., 45, 197-203.

Lu, B.R. (1999), Taxonomy of the genus Oryza (Poaceae): historical perspective and current status. Int. Rice Res. Notes, 24, 4-8.

Oliveira, G.C.X. (1992), Padrões de variação fenotípica e ecologia de Oryzae (Poaceae) selvagens da Amazônia. MSc Thesis, Escola Superior de Agricultura "Luiz de Queiroz", Universidade de São Paulo, Piracicaba, Brazil.

Oliveira, G.C.X. (1994), Geographic distribution of wild Oryza species in Brasil. In-Investigations of plant genetic resources in the Amazon basin with the emphasis on the genus Oryza: Report of 1992/93 Amazon Project, ed. H. Morishima P.S. Martins. The Monbusho International Scientific Research Program, Mishima, pp. 10-15.

Oliveira, G.C.X. (2002), A molecular phylogenetic analysis of Oryza L. based on chloroplast DNA sequences. PhD Thesis, Washington University, St. Louis, United States of America.

Rubim, M.A.L. (1994), A case study on life-history of wild rice- from germination to emergence of inflorescence. In-Investigations of plant genetic resources in the Amazon basin with the emphasis on the genus Oryza: Report of 1992/93 Amazon Project, ed. H. Morishima P.S. Martins. The Monbusho International Scientific Research Program, Mishima, pp. 38-42.
SAS Institute Inc. (1993), SAS/STAT user's guide for personal computers, Version 6. 3.ed. Cary.

Shimamoto, Y.; Ohara, M. and Akimoto, M. (1994), Habitat conditions and plant characters of wild rice in the Central Amazon. In - Investigations of plant genetic resources in the Amazon basin with the emphasis on the genus Oryza: Report of 1992/93 Amazon Project, ed. H. Morishima P.S. Martins. The Monbusho International Scientific Research Program, Mishima, pp. 16-37.

Silva, E.F.; Ando, A.; Montalvan, R. and Tulmann Neto, A. (1999), Método prático para o cultivo de espécies silvestres do gênero Oryza. Sci. Agric, 56, 1005-1007.

Statsoft Inc. (1996), Statistica for Windows: Computer Program Manual. StatSoft Inco, Tulsa.

Tateoka, T. (1962), Taxonomic studies of Oryza. II. Several species complexes. Bot. Mag., 75, 455-461.

Vaughan, D.A. (1994), The wild relatives of rice: a genetic resources handbook. International Rice Research Institute, Manila.

Zamora, A.; Sánchez, E.; Quesada, T.; González, P.; Quesada, C.; Gámez, R. Espinoza, A.M. (1999), Especies silvestres, reserva de genes útiles para el mejoramiento del arroz. Paper presented at Jornadas de Investigación de la Universidade de Costa Rica, Universidade de Costa Rica, Costa Rica.

Received: February 08, 2006; Revised: December 08, 2006; Accepted: March 29, 2007. 